\title{
The significance of therapeutic waters of Swoszowice, Krzeszowice and Mateczny in the development of spa tourism
}

\author{
Znaczenie wód leczniczych Swoszowic, Krzeszowic i Matecznego \\ dla rozwoju turystyki uzdrowiskowej
}

\author{
Izabela Jamorska \\ Nicholas Copernicus University, Faculty of Biology and Earth Sciences \\ Institute of Geography, 9 Gagarina Str., 87-100 Toruń \\ e-mail:iza1984@umk.pl
}
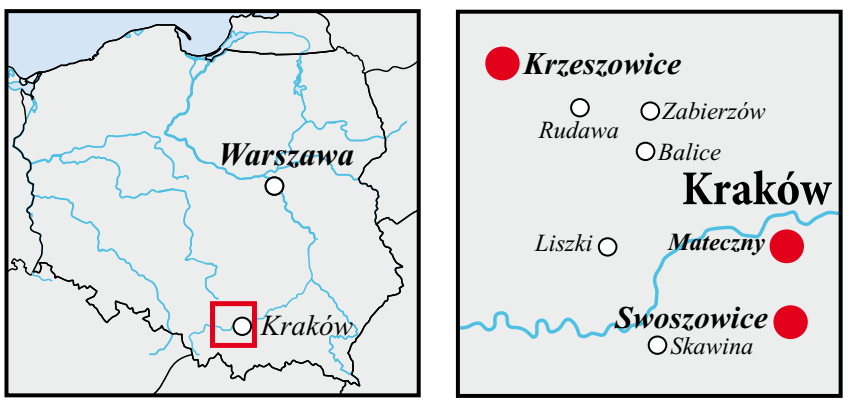

Abstract: Mineral waters have been applied for therapeutic purposes in Cracow since the fifteenth century. The complex geological structure of this area has had considerable influence upon various hydrogeological conditions. Sulphide waters in Cracow and in its vicinity are connected to the presence of gypsiferous formations occurring within the Miocene rocks deposits. Sulphide mineral waters help to treat such cases as: osteoarthritis, diseases of digestive system and nervous system, foodborne diseases, skin diseases, and illnesses of movument organs. The springs of those waters are located in a region that is particularly attractive to tourists. Both historical and natural attractions of Cracow and its neighbouring area create a big opportunity for further development of spa tourism there. This fashionable form of recreation may help old forgotten sulphide waters and Cracow health resorts revive their glamour.

Keywords: therapeutic water, groundwater conditions, turism, spa, recreations areas

Treść: Wody mineralne znane byty i stosowane w Krakowie w celach leczniczych od XVw. Skomplikowana budowa geologiczna tego obszaru wptywa na różnorodne warunki hydrogeologiczne. Wody siarczkowe Krakowa i okolic zwiqzane sq z obecnościq na tym obszarze utworów gipsonośnych wystęujacych $w$ obrębie piętra mioceńskiego. Siarczkowe wody lecznicze pomagaja w leczeniu takich dolegliwości jak: choroby zwyrodnieniowe stawów, schorzeń skóry, przewodu pokarmowego, systemu nerwowego, zatruć pokarmowych i pourazowych narzqdu ruchu. Źródła tych wód znajduja się watrakcyjnym turystycznie regionie Polski. Zarówno historyczne, jak i przyrodnicze atrakcje Krakowa i okolic stwarzaja ogromne możliwości rozwoju na tym obszarze turystyki uzdrowiskowej. Ta modna w obecnych czasach forma wypoczynku może pomóc zapomnianym wodom siarczkowym i uzdrowiskom krakowskim przywrócić ich dawnq świetlność.

Slowa kluczowe: woda lecznicza, warunki hydrogeologiczne, turystyka, uzdrowisko, obszary rekreacji

\section{Introduction}

Therapeutic properties of waters were recognised by inhabitants of the Far East as early as in the ancient times. Ancient Egyptians ran treatment centres offering hot baths to relieve tensions and lighten up the nervous system (Dukiet, 1967). At the time of the Roman Empire the first health resorts in the form of magnificent buildings, the so-called Roman thermae, were built. Both emperors, senators and common men took beneficial baths there (Golba, 2007). Mineral water bathing and drinking therapies developed greatly in the seventeenth and eighteenth centuries.

Although thousands of years have gone by, therapeutic waters still attract people's interest. The first information about therapeutic properties of waters in Poland was recorded in 1578 in the work of Wojciech Oczko, a doctor serving at the court of King Stefan Batory.

This study concerns mineral waters located within Cracow and its neighbouring area, and particularly the waters of Krzeszowice, Swoszowice and Mateczny.

It also discusses possibilities of their use for the development of spa tourism. Apart from their therapeutic properties, sulphide waters have not been fully used so far. Only Swoszowice gained the status of a health resort. Taking into consideration the fact that these water intakes are located near Cracow, one of the best developed tourist cities in Poland, they should become another attraction for both Polish and foreign tourists. With the growth of civilization diseases, hasty life and stress, the development of places that can constitute a peaceful enclave and can create a chance to experience nature should become a top priority. For introducing weak and strong sides of these places SWOT analysis was used. Due to a rich recreational offer and a positive attitude to a patient-tourist, such places could become famous in Poland, and they could also compete with other European health resorts.

\section{Characteristics of the study area}

The study area is located In the Malopolskie Voivodeship. According to Kondracki's division of Poland into the physical and geographical mesoregions (1998), this area belongs to several subprovinces: the Krakowsko-Częstochowska Upland, the Małopolska Upland, the Northern Carpathian Foothills, and the Western Outer Carpathians. 


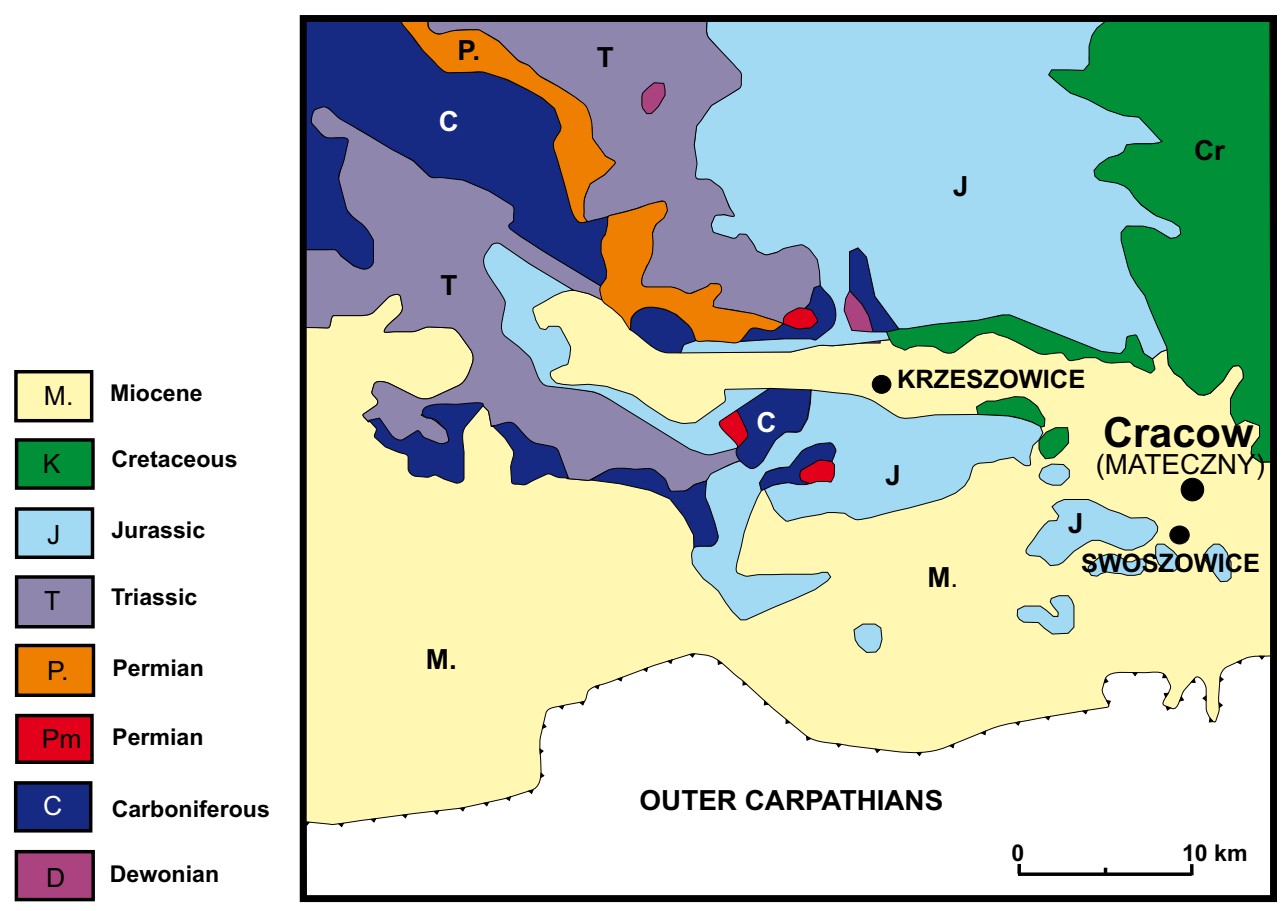

Fig. 1. Geological map of Cracow region without Quaternary deposits (Gradziński, 1993)

- Mapa geologiczna obszaru krakowskiego bez osadów czwartorzędowych (Gradziński, 1993)

With respect to the climate, three climatic regions can be differentiated in the Małopolska region: the Central Polish Uplands, the Carpathian Foothill Basins and the Carpathians. From a geological point of view, the region of Cracow is located in a special place - the limits of great structural units, among others: the Upper Silesian Depression, the CracowSilesian Monocline, the Nida Basin, and the Carpathians, the Carpathian Foredeep and the Carpathian forefield. All this results in diversity and complexity of the area where faults are basic tectonic elements (Rutkowski, 1993).

The occurrence of therapeutic waters is closely related to the Carpathian Foredeep (Fig. 1).

The Early to Middle Miocene Carphatian Foredeep in Poland developed as a peripheral foreland basin related to the moving Carpathian front. The Polish Carpathian Foredeep (about $300 \mathrm{~km}$ long and $100 \mathrm{~km}$ wide), is part of the large sedimentary basin, which stretches for more than $1300 \mathrm{~km}$, from the Austria to Romania. Like other foreland basins, the Carpathian Foredeep is asymetric and filled with predominantly clastic sediments of the Miocene age up to $3 \mathrm{~km}$ thick (Oszczypko et al., 2006).

The area of the Małopolskie Voivodeship contains 25 mineral water deposits which are considered to have therapeutic properties. Among these only four are sulphide waters. The biggest and oldest of these is found in Swoszowice, District $10^{\text {th }}$ of the city of Cracow, discovered in the fifteenth century. The others are: Cracow-Mateczny and Krzeszowice (Tab.1) (Porwisz et al., 2008).

Tab.1. Essential characteristics of the therapeutic waters of the Swoszowice, Krzeszowice and Mateczny (www.mineralne.pig.gov.pl) - Podstawowa charakterystyka wód leczniczych Swoszowic, Krzeszowic i Matecznego (www.mineralne.pig.gov.pl)

\begin{tabular}{|c|c|c|c|c|c|}
\hline $\begin{array}{l}\text { Borehole } \\
\text { (Otwór) }\end{array}$ & $\begin{array}{c}\text { Depth } \\
\text { (Głębokość) } \\
{[\mathrm{m}]}\end{array}$ & $\begin{array}{l}\text { Stratigraphy } \\
\text { (Stratygrafia) }\end{array}$ & $\begin{array}{l}\text { Lithology } \\
\text { (Litologia) }\end{array}$ & $\begin{array}{c}\text { Aquifer } \\
\text { (Poziom } \\
\text { wodonośny) }\end{array}$ & $\begin{array}{l}\text { Types of water } \\
\text { (Typ wody) }\end{array}$ \\
\hline \multicolumn{6}{|l|}{ SWOSZOWICE } \\
\hline Źródło Główne & $\begin{array}{c}\text { spring } \\
\text { (źródło) }\end{array}$ & $\operatorname{Tr}$ (miocene) & $\begin{array}{c}\text { marls (margle), } \\
\text { slate(łupki) }\end{array}$ & - & SO4-HCO3-Ca-Mg, H2S \\
\hline Napoleon & $\begin{array}{l}\text { spring } \\
\text { (źródło) }\end{array}$ & $\operatorname{Tr}$ (miocene) & $\begin{array}{c}\text { marls (margle), } \\
\text { slate(łupki) }\end{array}$ & - & SO4-HCO3-Ca-Mg, H2S \\
\hline \multicolumn{6}{|l|}{ KRZESZOWICE } \\
\hline Zdrój Główny & $\begin{array}{l}\text { spring } \\
\text { (źródło) }\end{array}$ & $\operatorname{Tr}($ miocene $)$ & $\begin{array}{l}\text { gypsum(gipsy), } \\
\text { claystone } \\
\text { (iłowce) }\end{array}$ & - & SO4-HCO3-Ca-Mg, H2S \\
\hline \multicolumn{6}{|l|}{ MATECZNY } \\
\hline Geo-2A & 37 & $\operatorname{Tr}($ miocene $)$ & sand (piasek) & $30-34$ & $\mathrm{SO} 4-\mathrm{Cl}-\mathrm{HCO} 3-\mathrm{Na}, \mathrm{H} 2 \mathrm{~S}$ \\
\hline M3 & 51 & $\operatorname{Tr}($ paleogen $)$ & sand (piasek) & $44-48$ & SO4-Cl-Na-Mg-Ca, H2S \\
\hline M4 & 36 & $\operatorname{Tr}($ miocene $)$ & marls (margle) & $26-34$ & SO4-Cl-Na-Ca, H2S \\
\hline
\end{tabular}




\section{Use of therapeutic waters and tourist attractions of Swoszowice, Krzeszowice and Mateczny}

Swoszowice, similarly to most Polish health resorts, is located in one of the most beautiful regions in our country. It is a picturesque green oasis in the southeast part of Cracow. These are the spa park established in 1811, the forests and the River Wilga that should attract overworked inhabitants of Cracow who live in a noisy and overcrowded city. Sulphide waters constitute the key capital of this resort. Their history is closely related to the existence of sulphur mine which operated there from 1422 to 1786 .

As early as in the fifteenth century sulphate waters from these springs were used in therapeutic baths which is mentioned in Guidebook of the Health Resorts from 1878. Wojciech Oczko, a court doctor of King Stefan Batory writes about bathing in Swoszowice in his work Cieplice (1578). It is the first balneologic document and the first publication of this kind written in Polish (Ney, 2002).

The area of this spa contains sulphide waters of a $\mathrm{SO}_{4}$ $\mathrm{HCO}_{3}-\mathrm{Ca}-\mathrm{Mg}, \mathrm{H}_{2} \mathrm{~S}$ type (Fig. 2).

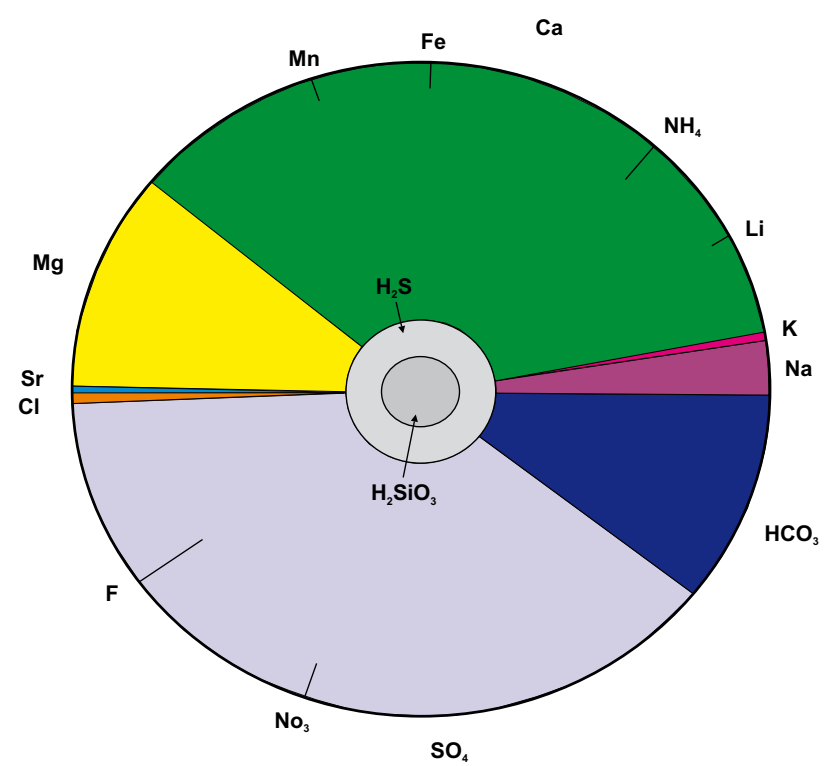

$1 \mathrm{~mm}^{2}-0,25 \mathrm{mg} / \mathrm{l}$

Fig. 2. Udluft circular diagram of water chemistry for „Źródło Główne” - Chemizm wód Źródła Głównego przedstawiony na wykresie Udlufta

Their uniqueness is favoured by hydrogen sulphide (approx. $60 \mathrm{mg} / \mathrm{l})$. At present, the only exploited mineral water intake within the Swoszowice mining area is the Main Spring (Fig. 3).

The spring „Napoleon" contains water of the same type. It is surrounded by a concrete ring. The outflowing water is not, however, used for therapeutic purposes but runs off as a small stream to the River Wilga.

The formations of the sulfurated gypsum series intersected by former mine workings make a reservoir of therapeutic waters. It is of a fissure-karst charakter, hence it offers considerable permeability and ability to accumulate water. At the bottom of the series of evaporators there are clastic

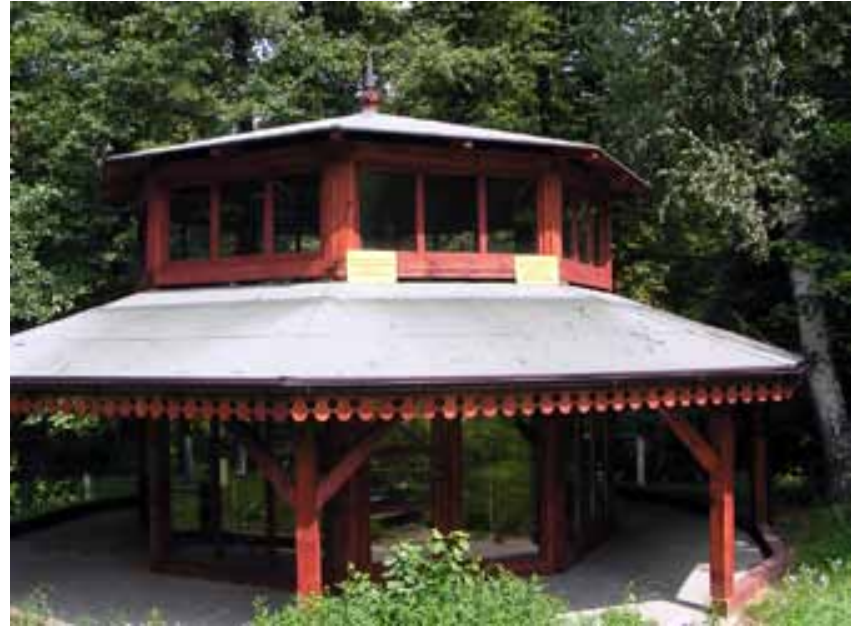

Fig. 3. The Main Spring - Swoszowice, phot. I. Jamorska • Źródło Główne - Swoszowice, fot. I. Jamorska

formations: conglomerates, sandstones and sands, and also strongly sanded argillaceous slates. Similar deposits were recorded within the series of evaporators (Kleczkowski, Myszka, 1989).

The climate and bioclimate of Swoszowice have therapeutic properties as well. Taking into considerations other parts of Cracow, the area of Swoszowice is definitely more favourable, and its properties may be applied in climatic treatment of motor disorders and rheumatic diseases. The bioclimate of Swoszowice has properties that toughen the circulatory and thermoregulatory systems. The most favourable period lasts from April to September. It is possible to apply motor heliotherapy at this time. Despite a close distance to the city centre, the levels of air pollutiants stay below the norm. Similar results were also obtained for noise measurements. The area of the health resort hardly poses environmental nuisance (Porwisz, et al., 2008). The most favourable conditions for climatic therapy as well as for relax and recreation can be recorded in the Spa Park (Fig. 4).

The highest content of plant etheric oils in the air is of considerable importance here. These oils have prophylactic and therapeutic properties for fighting high blood pressure

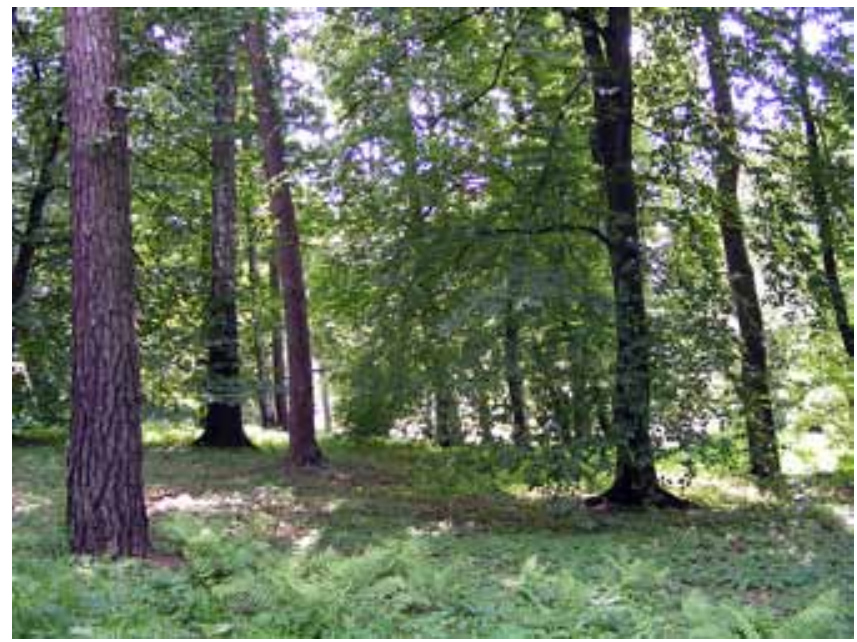

Fig. 4. The Spa Park, phot. I. Jamorska - Park Zdrojowy, fot. I. Jamorska 
and asthma, as well as they reveal soothing properties (Porwisz, et al., 2008). The Spa Park was established by the decision of its former owner, Prof. Radwański in approximately 1820. In the concern for the patients who complained about the lack of shade, he ordered to plant young lindens, elm trees and harnbeams, presently the oldest specimen in the park. Nowadays the Spa Park serves both inhabitants, patients and tourists. Two tourist routes: blue and black ones go through it. Moreover, there are deciduous trees reaching the height of 25 metres. They are often 180 years old. The most valuable specimen were classified as natural landmarks. These are among others small-leaved lindens and elm trees. In the past a pond surrounded by beautiful weeping willows used to be an attraction. Nowadays it is overgrown by common reed (http://malopolskie.parki.org/krkswoszowice2/).

The Nature Treatment Institute is located in the Spa Park. Its present condition reflects changeable political situations in the history of Poland among others, and is the result of transfers of ownership rights. Its prosperous period falls on the years preceding the Second World War. The war brought about devastation. During the interwar period its status was revived and during the Nazi occupation Baths were extended. On 25th July 1974 Swoszowice gained the status of a Health Resort, however, due to the lack of funds renovation works were interrupted. The Nature Treatment Institute is situated in the baths - in the old building. Electrotherapeutic procedures are carried out in the modernized "Parkowa" pavilion (Fig. 5).

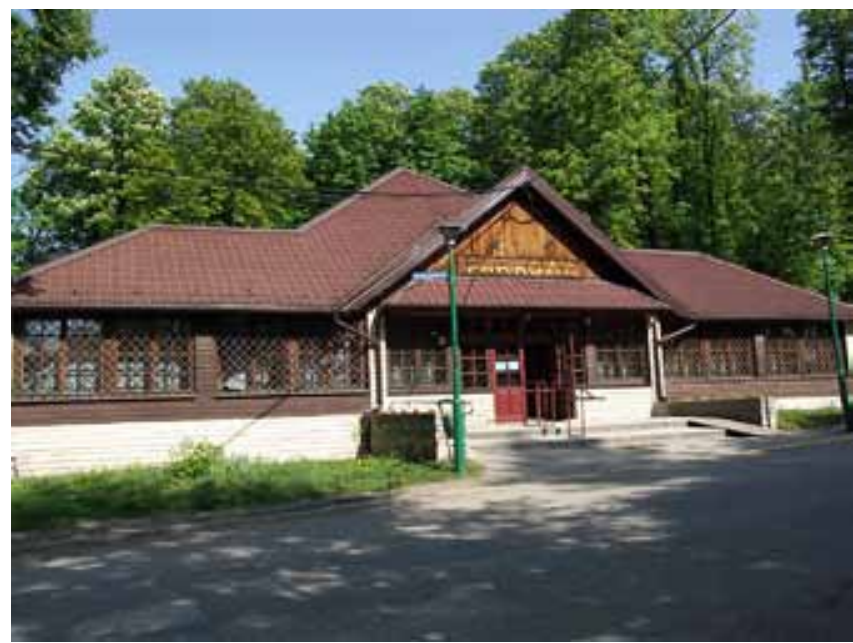

Fig. 5. „Parkowa” pavilion, www.uzdrowisko.krakow.pl • Pawilon „Parkowa”, www.uzdrowisko.krakow.pl

That is where customers' office, a restaurant and a café are found. The patients live in the „Sun” pavilion and partially in the baths building. In the present building complex the following therapeutic procedures are offered: sulphate baths, peat poultice, underwater massage, dry massage and whirpool baths, radiations: diadynamics, terapuls, ionophoresis, and acupressure.

Annually, there are approximately 21600 out-patient and 3700 in-patient procedures carried out. The staff includes: 2 doctors, 12 nurses, 6 specialists and 15 assisting workers. So far the Water Treatment Institute has recorded particularly high effectiveness in treating patients suffering from rheumatoid arthritis and ankylosing spondylitis.
According to its definition, a health resort is a town rich in natural therapeutic resources, i.e. mineral waters used in bathing and drinking therapies, and additionally it is located in a favourable climate. The town should also provide health service and indispensable facilities. Currently the health resort fulfils two elementary functions: therapeutic and tourist ones. The above quoted facts prove that Swoszowice meet all the necessary requirements presented in the Polish Norm PN-91/ ZZ-11000 concerning health resorts. Tourism remains another function to carry out. Apart from offering therapeutic procedures, many Polish and foreign health resorts take advantage of their geographic locations to create and promote active forms of recreation. Swoszowice may also offer different forms of active holidays. The Voivodeship Sports Club "Krakus" hosts three sports sections: football, cycling and horse-riding. The horse-riding centre offers classes of horseriding, rehabilitation and contests. Rehabilitation for children suffering from cerebral palsy with biocurrents while horseriding together with the therapeutic procedures at the Nature Treatment Institute has gained great recognition in Poland. The most recommended method of convalescence for elderly patients is to stroll in the above described Spa Park along the marked paths and tourist routes. A stay in the health resort may be enriched with an excursion (a pilgrimage) to the World Centre of Veneration of the Image of the Divine Mercy in Cracow-Łagiewniki, a famous sanctuary and a sightseeing trip around Cracow, to visit the Royal Castle, among others.

Swoszowice is approximately $3 \mathrm{~km}$ away from the centre of Cracow. The distance to the Wieliczka Salt Mine is similar. Apart from sightseeing the famous salt mine patients can take advantage of beneficial activity of salt in special grottos adapted to serve therapeutic purposes.

The exceptional qualities of natural treatment and tourism are not properly exploited in Swoszowice. The springs of sulphide water, so unique in Europe, are used merely in $25 \%$. This fact is related to economic issues but also results from long-term negligence to modernize the Institute. Several attempts to improve the condition of the historical complex of the Nature Treatment Institute are planned.

Krzeszowice is located within the Krakowska Upland, in the centre of the Krzeszowicki Trough, 25 kilometers to the west of Cracow (Fig. 6).

In this area the Krzeszowicki Trough narrows down to the width of nearly $2 \mathrm{~km}$.. It is a particularly picturesque place that is very diversified geomorphologically and geologically.

Two mineral water aquifers of different chemism and depths have been documented in the area of Krzeszowice. The lower aquifer is found in cracked and karst limestones of the Upper Jurassic that show favourable conditions for carrying and storing waters, similarly to the overlying sandy deposits of the Cretaceous and Palaeogene. The other, higher aquifer is linked to the Miocene gypsums within which traces of karst washing and several cracks and fissures can be observed. Their presence and karst processes make the complex of deposits with gypsums a place where mineral waters of sulphate type accumulate and circulate (Ney, 2002).

Mineral waters of Krzeszowice are captured by the "Main Spring” (Fig. 7), whose exploitation resources amount 1.61 $\mathrm{m} 3 / \mathrm{h}$ with the depression of $2.3 \mathrm{~m}$. 


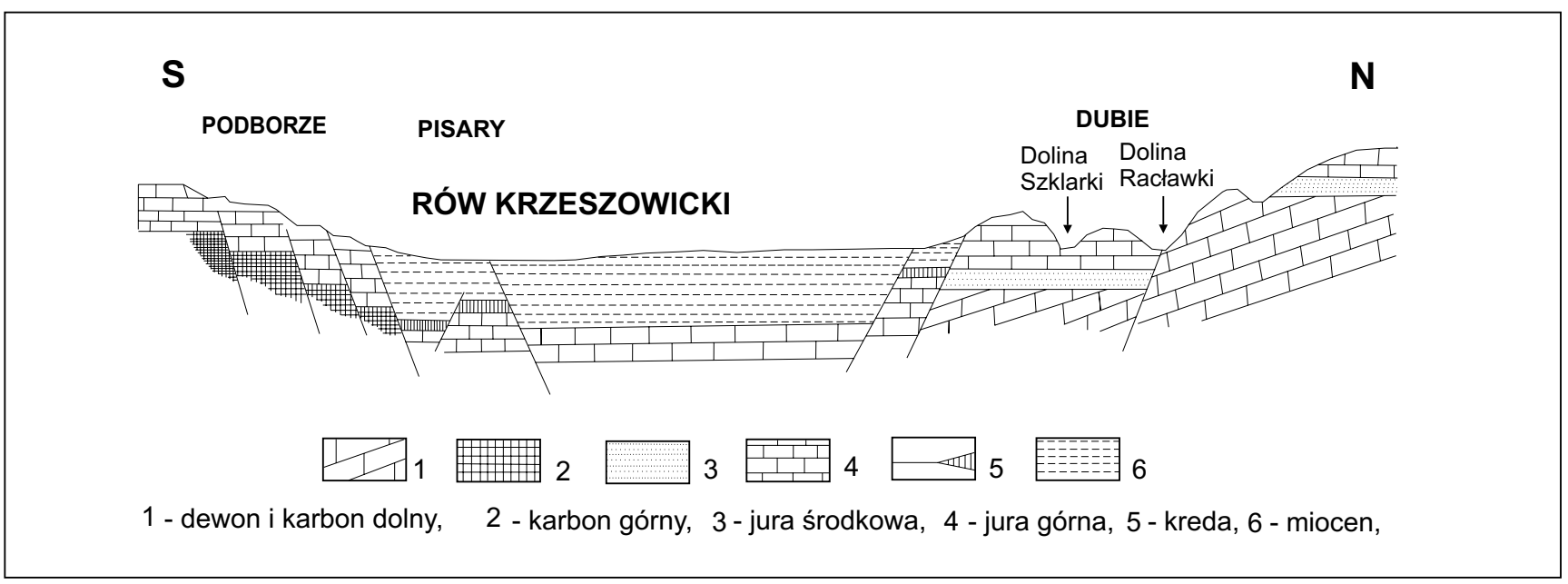

Fig. 6. Geological cross-section across Krzeszowicki Trough, (Gradziński, 1972)

- Przekrój geologiczny przez Rów Krzeszowicki (Gradziński, 1972)

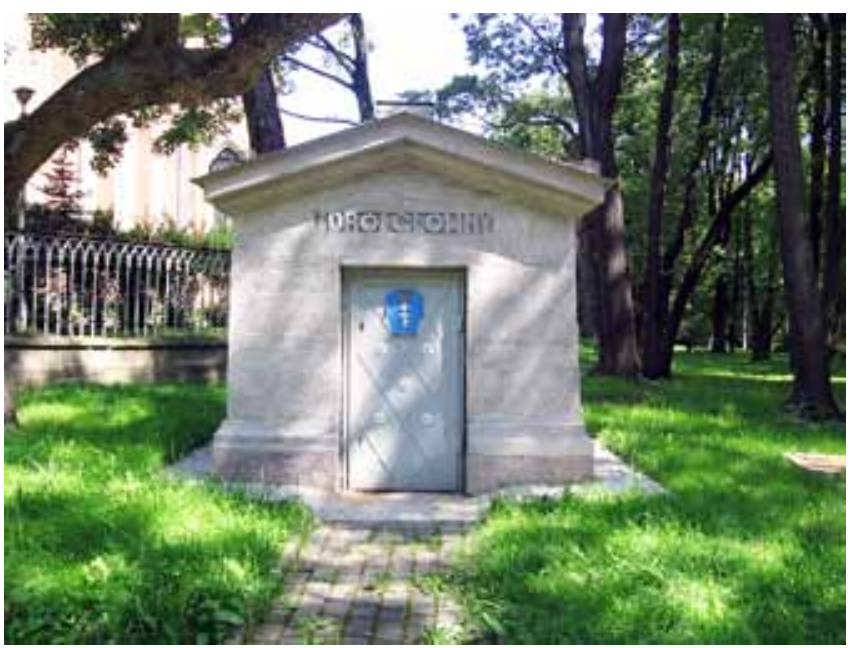

Fig. 7. The Main Spring - the spring of sulfurous water surrounded and covered by a turret, phot. I. Jamorska $•$ Zdrój Główny - zdrój wody siarczkowej, ocembrowany i nakryty drewniana wieżyczka, fot. I. Jamorska

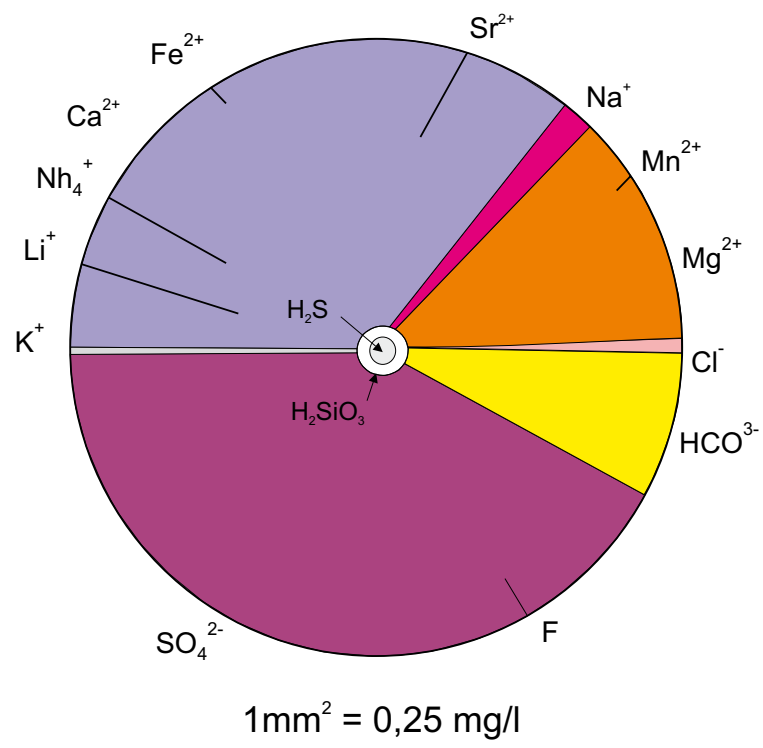

Fig. 8. Udluft circular diagram of water chemistry for The Main Spring • Chemizm wód Zdroju Głównego przedstawiony na wykresie Udlufta

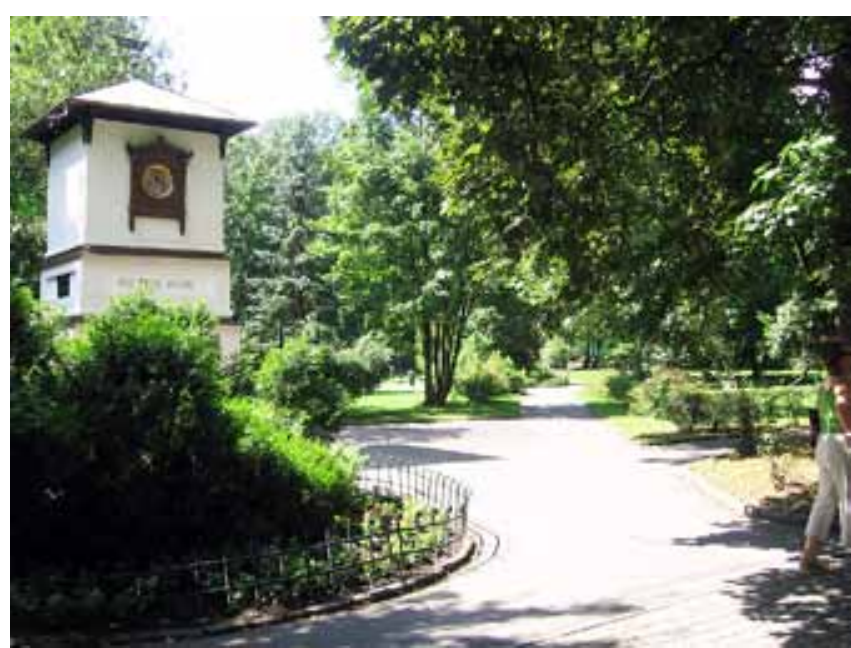

Fig. 9. The Chapel - originally it was a reservoir of sulfurous water, phot. I. Jamorska $•$ Kapliczka - pierwotnie zbiornik wody siarczkowej, fot. I. Jamorska

This is a natural spring captured in a well that is $4.76 \mathrm{~m}$ deep. The outflowing water is of the SO4-HCO3-Ca-Mg, H2S type and has the H2S content of approximately $6 \mathrm{mg} / \mathrm{l}$ (Fig. 8).

The chapel originally it was a reservoir of sulfurous water, which was pumped from the Main Spring and then, through wooden pipes transported to the bath (Fig. 9).

The history and development of the health resort begins in the mid-eighteenth century when dr Jan Gotfryd Leonhardi carried out the studies of the properties of the sulphate water ordered by Prince August Czartoryski. In 1778 the "Main Spring" was timbered and the first baths were constructed. After the death of Priest Czartoryski the spa was taken over by his daughter, Izabela Lubomirska who developed the complex and introduced the concept of combining treatment with entertainment. At that time Krzeszowice had a period of prosperity. The regular balls attracted guests from Cracow and also from more distant places.

The Second World War brought about destruction and closure of the health resort. It was re-opened in 1964 because of miners for who sulphide water appeared to save weakened health. Footballers of the "Wisła" FC in Cracow treated their injuries there undergoing very good rehabilitation procedures 


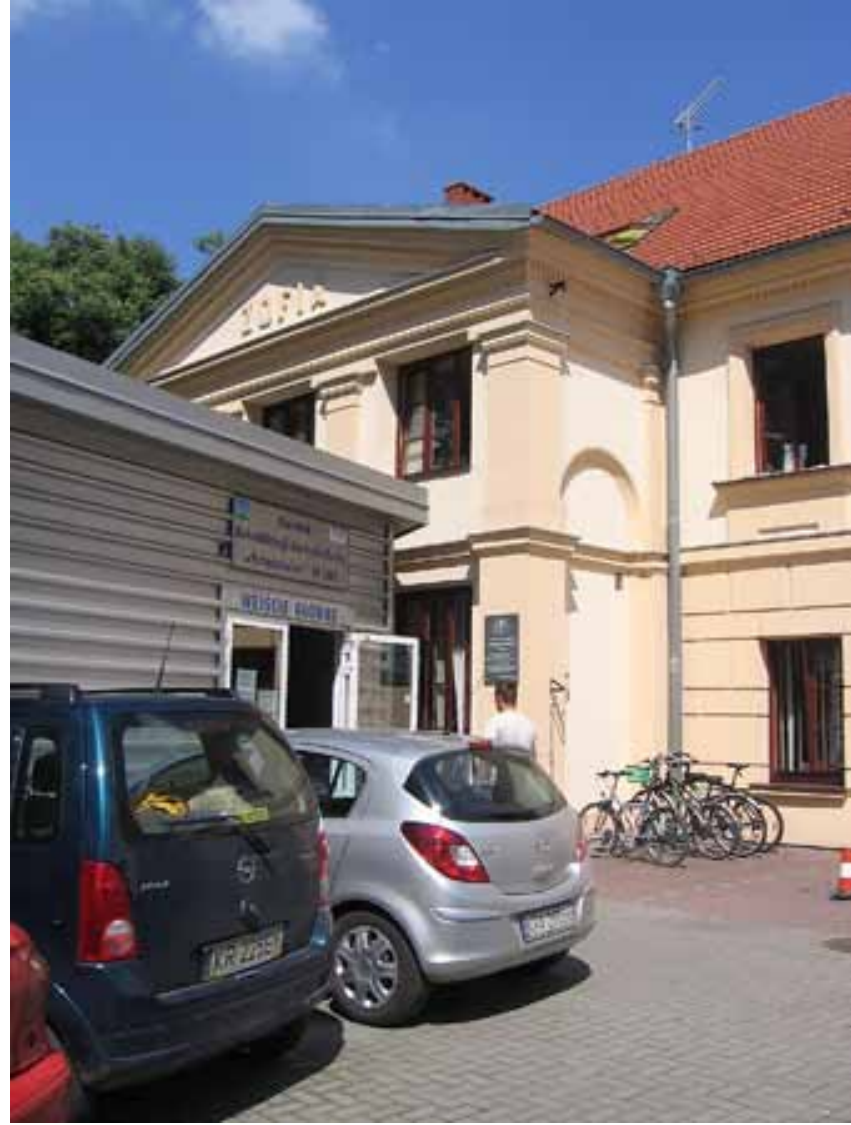

Fig. 10. Health Care Facility and Rehabilitation Centre for MuscleSkeletal, phot. I. Jamorska • Ośrodek Rehabilitacji Narządu Ruchu, fot. I. Jamorska

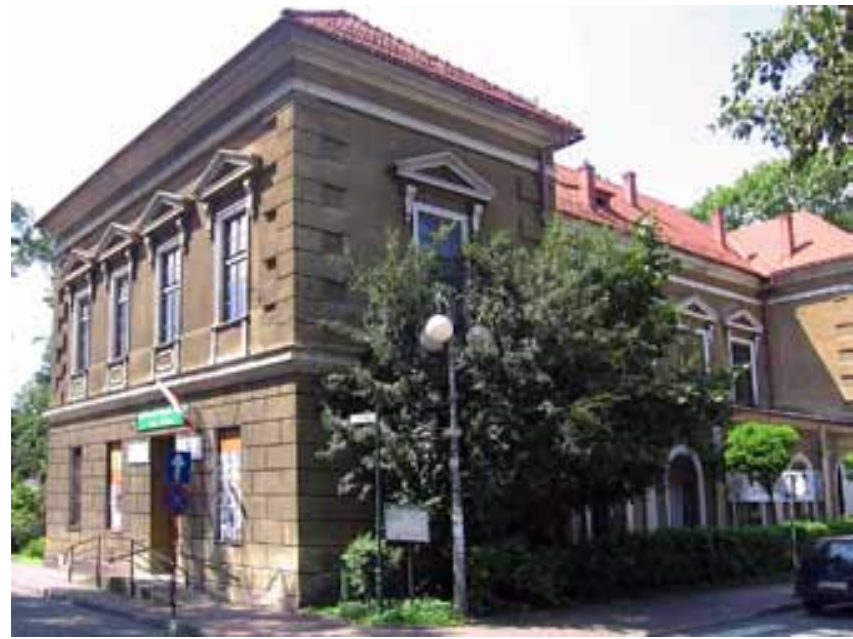

Fig. 11. „Vauxhall” Palace, I. Jamorska • Pałac „Vauxhall”, I. Jamorska

(www.krzeszowice.net4.pl). In 1999 the centre began to operate as an Independent Health Care Facility and Rehabilitation Centre for Muscle-Skeletal (Motor) Organs - "Krzeszowice" (Fig. 10).

Duchess Lubomirska's idea to combine therapy with entertainment is still up-to-date. It is widely understood that health tourism, including spa tourism, will be one of the most intensely developing branches. Similarly to Swoszowice, apart from the occurrence of valuable mineral waters, the town of Krzeszowice can take pride in numerous monuments (Fig. $11,12,13)$, several walking and bicycle routes.

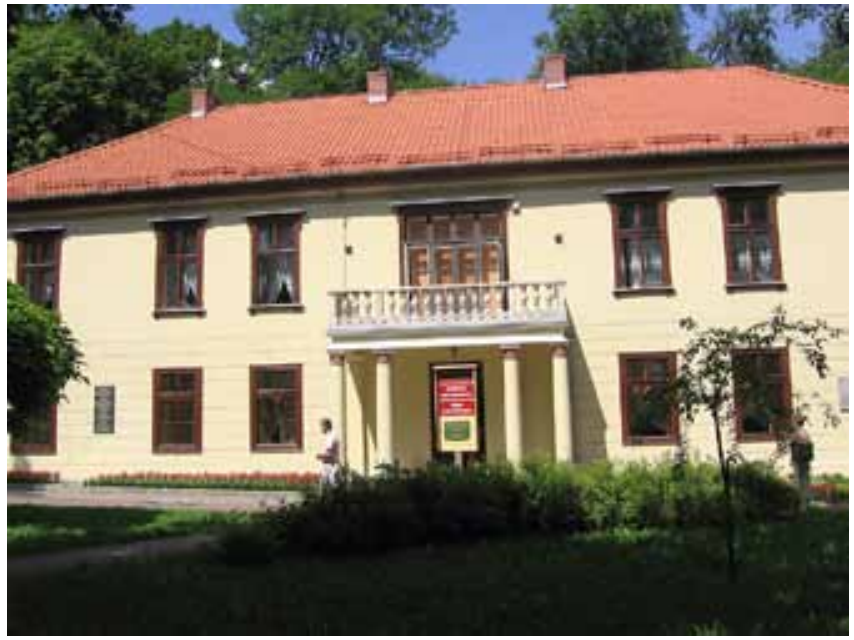

Fig. 12. The Old Palace - classistic building, adapted for the needs of the Potocki family in 1820 - 1822, phot. I. Jamorska • Pałac Stary - klasycystyczny budynek powstały w latach 1820 - 1822, który stał się siedziba rodu Potockich, fot. I. Jamorska

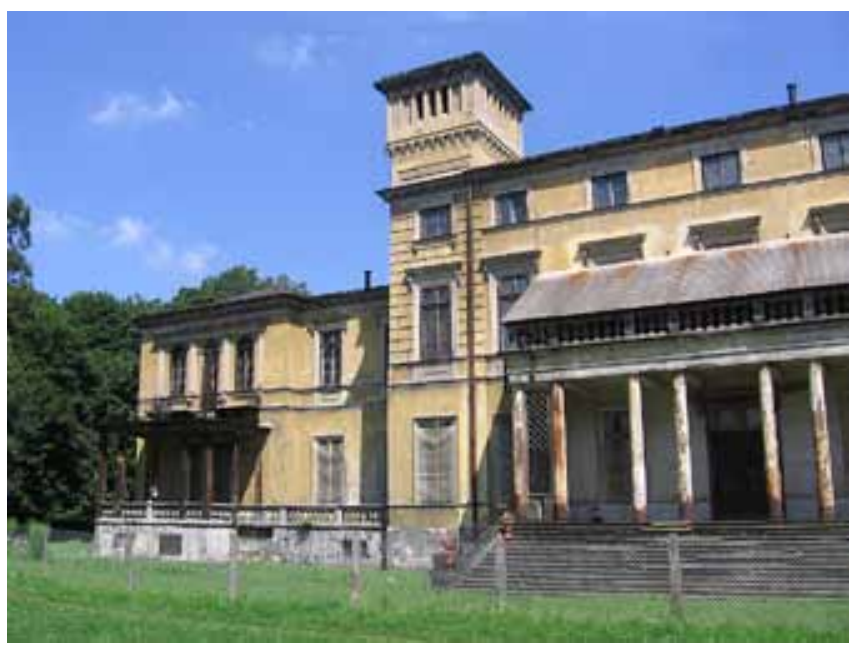

Fig. 13. The New Palace, phot. I. Jamorska - Pałac Nowy, fot. I. Jamorska

The development of tourism in this area may also be supported by the presence of numerous Landscape Parks (Fig. 14) and Nature Reserves.

There is the Papal Trail running through Krzeszowice, which made walking and bicycle trips more attractive for Karol Wojtyła (John Paul II) and St. Mary’s trail (Fig. 15).

Patients can go on educational excursions along the coal mining route, admire wooden architecture and go down an educational path leading through the premises of the former papal closure to see the nature's treasures of the Eliaszówka Valley Reserve and the Convent of Barefoot Carmelites (www.krzeszowice.pl).

Good communication network can also promote the development of spa tourism. The airport and an increasing number of cheap airlines make this place easily accessible for foreign tourists. Both Swoszowice and Krzeszowice should adapt to prevailing trends. Mineral waters and a very long tradition of travelling to such resorts are undoubtedly assets for those locations which can outshine other recreational places. Rich history of these places, direct contact with nature should be a magnet for the society living a hasty life in bigger cities. 


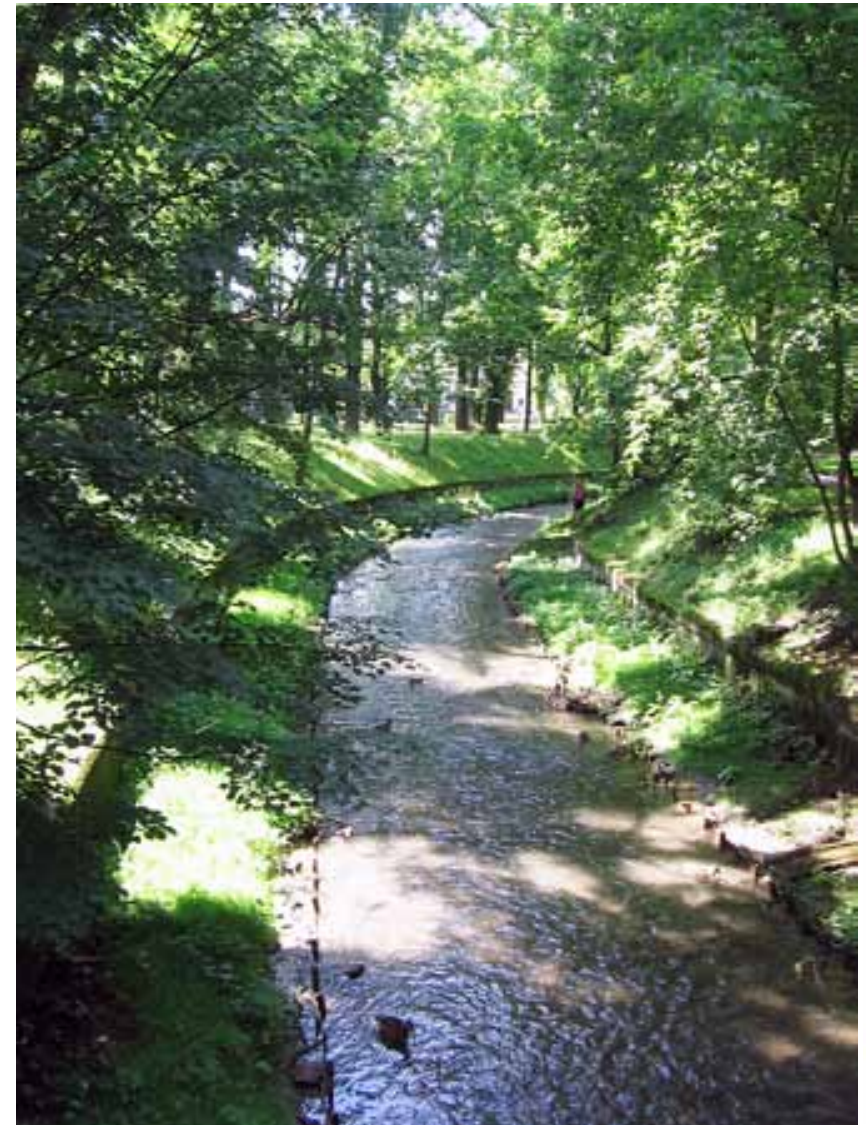

Fig. 14. The Spa Park - Krzeszowice, phot. I. Jamorska - Park Zdrojowy - Krzeszowice, fot. I. Jamorska

Spa tourism has undergone chances in many European countries in recent years. Health resorts are no longer for the elderly only. More and more younger people have began to appreciate the delights of health resorts which offer revival of vital forces but also active forms of recreation. More and more European health resorts consider the needs of the young and open up popular SPA and Wellness centres.

Going beyond standard therapeutic and prophylactic procedures seems to be the biggest challenge for the health resorts in Swoszowice and Krzeszowice. However such a change requires substantial investment which is a crucial problem for most Polish health resorts. The European Union structural funds may provide a solution to this problem. The Polish Tourist Organisation, a governmental representative responsible for the development of the image of Poland, has decided to introduce a series of marketing campaigns promoting Polish cities and towns in the years 2008-2012. Therefore, this is an excellent opportunity to undertake attempts to adapt such places to the needs and expectations of tourists.

Cracow-Mateczny is a tourist resort which has adjusted in a considerable way to meet the prevailing spa trends (Fig. 16).

The peculiar fact is that sulphide spring waters are located at the crossing of Mateczny roundabout, in the centre of Cracow. Sulphide waters were discovered incidentally while searching for potable water in the garden of Antoni Mateczny. Using that spring, in the year 1905, Antoni Mateczny opened the Sulphate and Brine Bath Centre, commonly called "Mateczny" (Fig. 17).

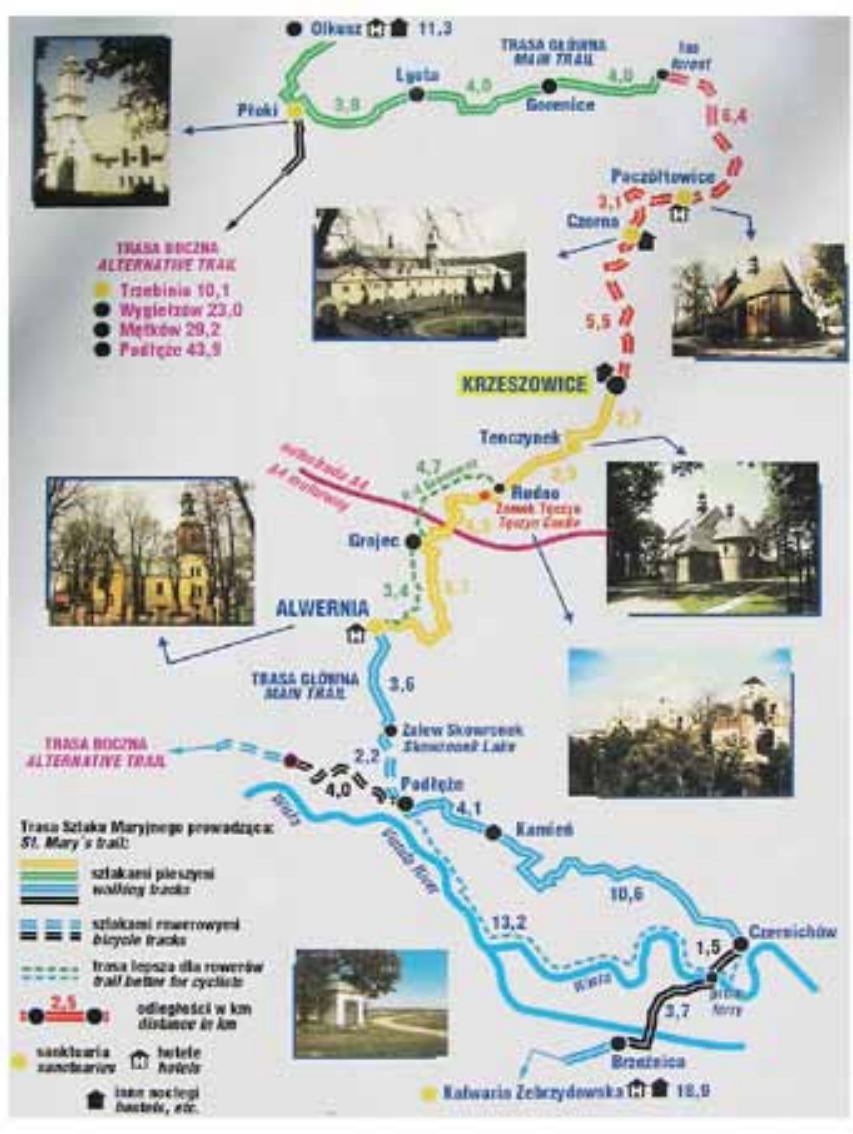

Fig. 15. St. Mary's trail, phot. I. Jamorska • Szlak Maryjny, fot. I. Jamorska

Hydrological conditions of these waters are fairly well recognised owing to numerous boreholes. They are related to the deep karst pockets in the Jurassic limestones filled (Fig. 18) with fine sands of the Palaeogene and marl-limestones of the Miocene (Kleczkowski, Myszka, 1989).

In all Mateczny boreholes two aquifers were distinguished. The upper free fresh water aquifer is connected with the Quaternary formations and the lower artesian mineral water aquifer with the Miocenes formations. In sands and gravels these are marl-limestones and the Miocene clays that separate mineral water deposits from the Quaternary aquifer. These deposits serve as a natural protection for the mineral waters against pollution of an anthropogenic origin, which is particularly dangerous in the city centre. Mineral waters of Mateczny are captured by M-4, M-3 and Geo-2A (Fig. 19) boreholes.

The area of this spa contains sulphide waters of a $\mathrm{SO}_{4}-\mathrm{Cl}-$ $\mathrm{Na}-\mathrm{Ca}, \mathrm{H}_{2} \mathrm{~S}$ type, $\mathrm{SO}_{4}-\mathrm{C}_{1}-\mathrm{Na}-\mathrm{Mg}-\mathrm{Ca}, \mathrm{H}_{2} \mathrm{~S}$ (M3) and $\mathrm{SO}_{4}-\mathrm{Cl}-$ $\mathrm{HCO}_{3}-\mathrm{Na}, \mathrm{H}_{2} \mathrm{~S}\left(\mathrm{GeO}_{2} \mathrm{~A}\right)$.

Sulphide waters are used here for therapeutic baths. They help to treat rheumatic diseases, injury-induced motor organs and skin diseases. Due to a high concentration of precious bio-elements, these waters have been bottled and sold under the trade name "Krakowianka" since 1970. The uniqueness of this water lies in the mutual proportion between the content of calcium and magnesium in a litre, which guarantees better absorption by the organism (Rajchel, 2000). In the year 2003, IPR Polska acquired the real property consisting of historic buildings located in a park area of over 3 ha. It is the intention 


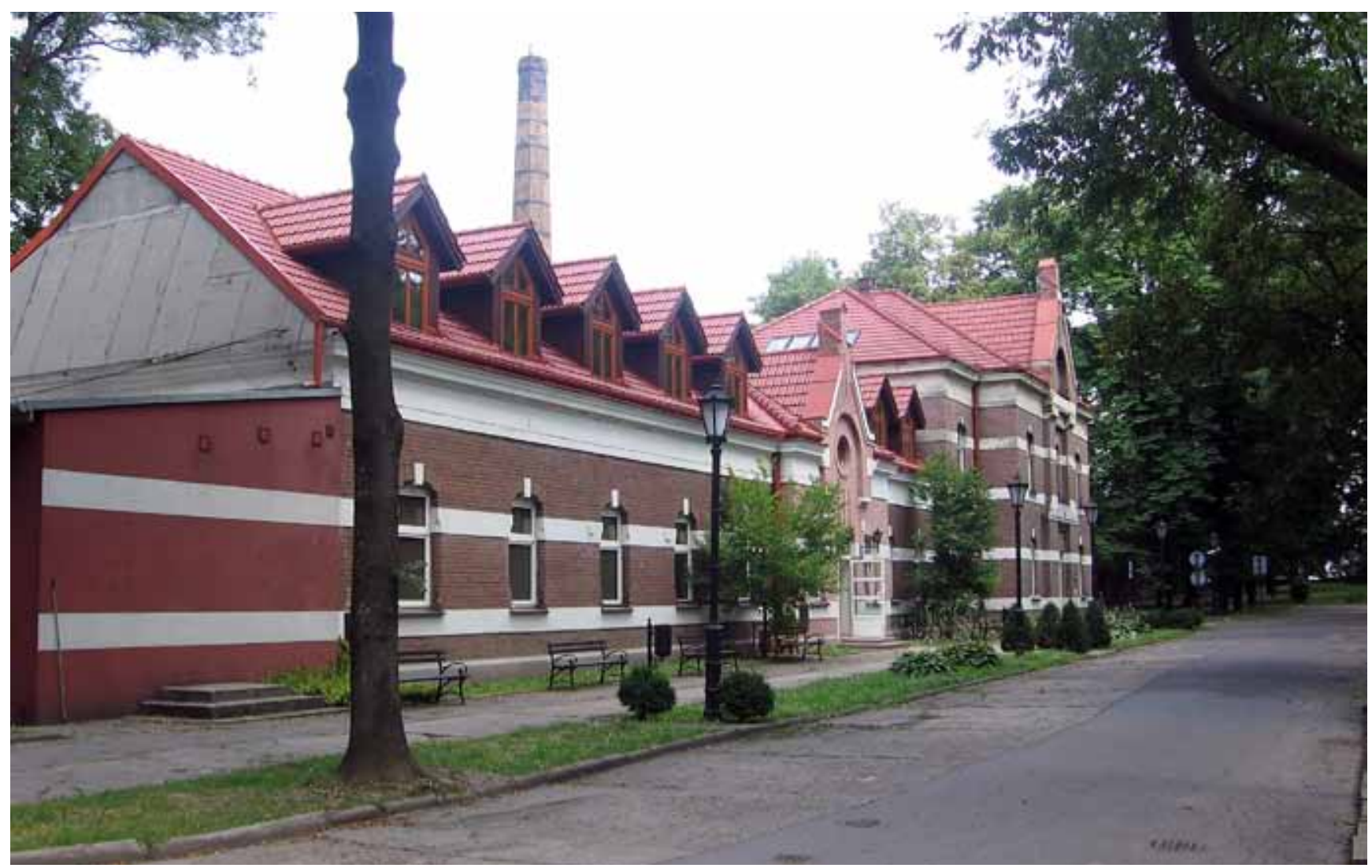

Fig. 16. Day Spa Relax Care in Cracow, phot. I. Jamorska • Ośrodek Day Spa Relax Care w Krakowie, fot. I. Jamorska

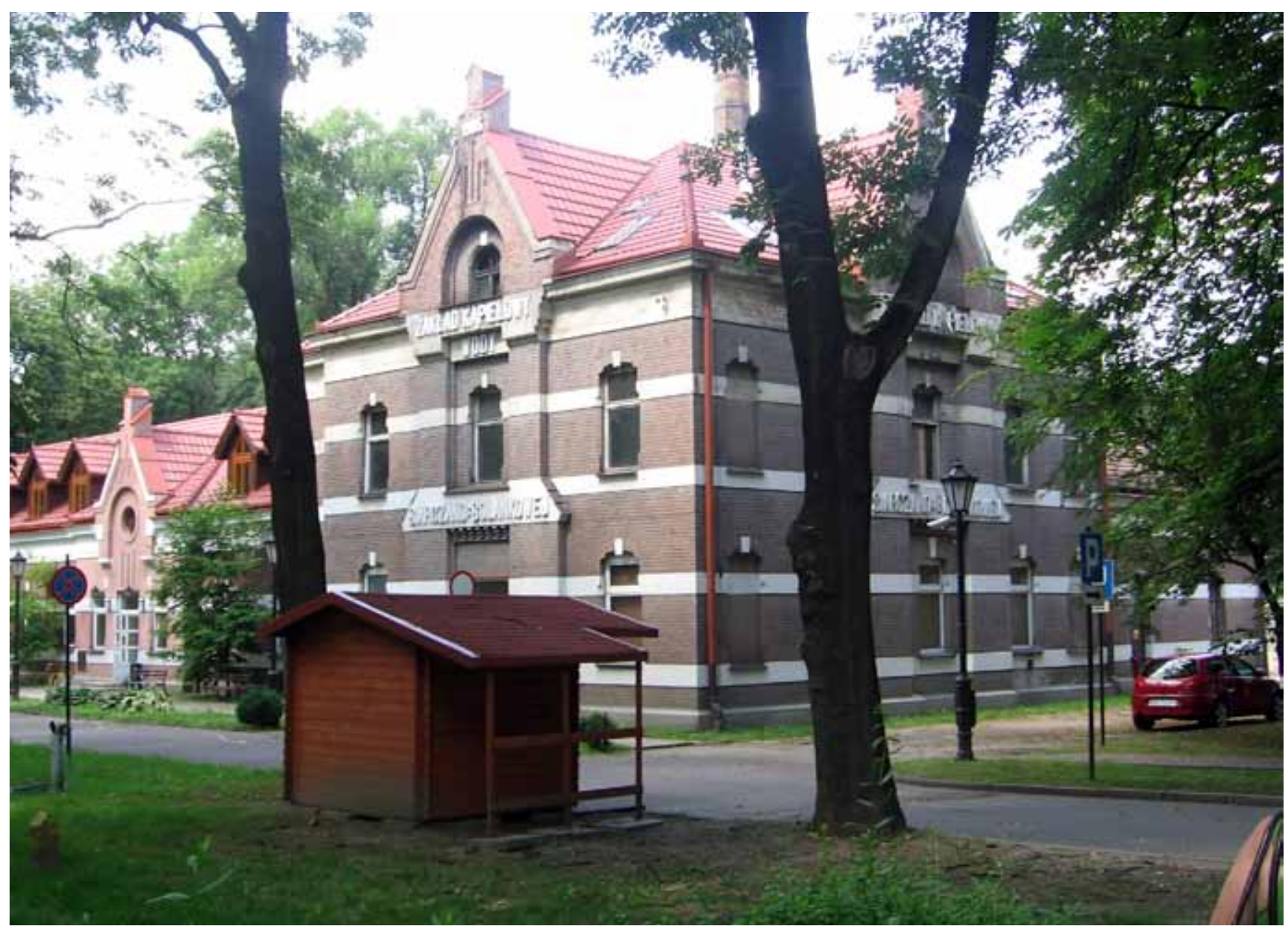

Fig. 17. Sulphate and Brain Bath Centre - 1905, phot. I. Jamorska • Zakład Kąpielowy wody siarczano-solankowej - 1905, fot. I. Jamorska 


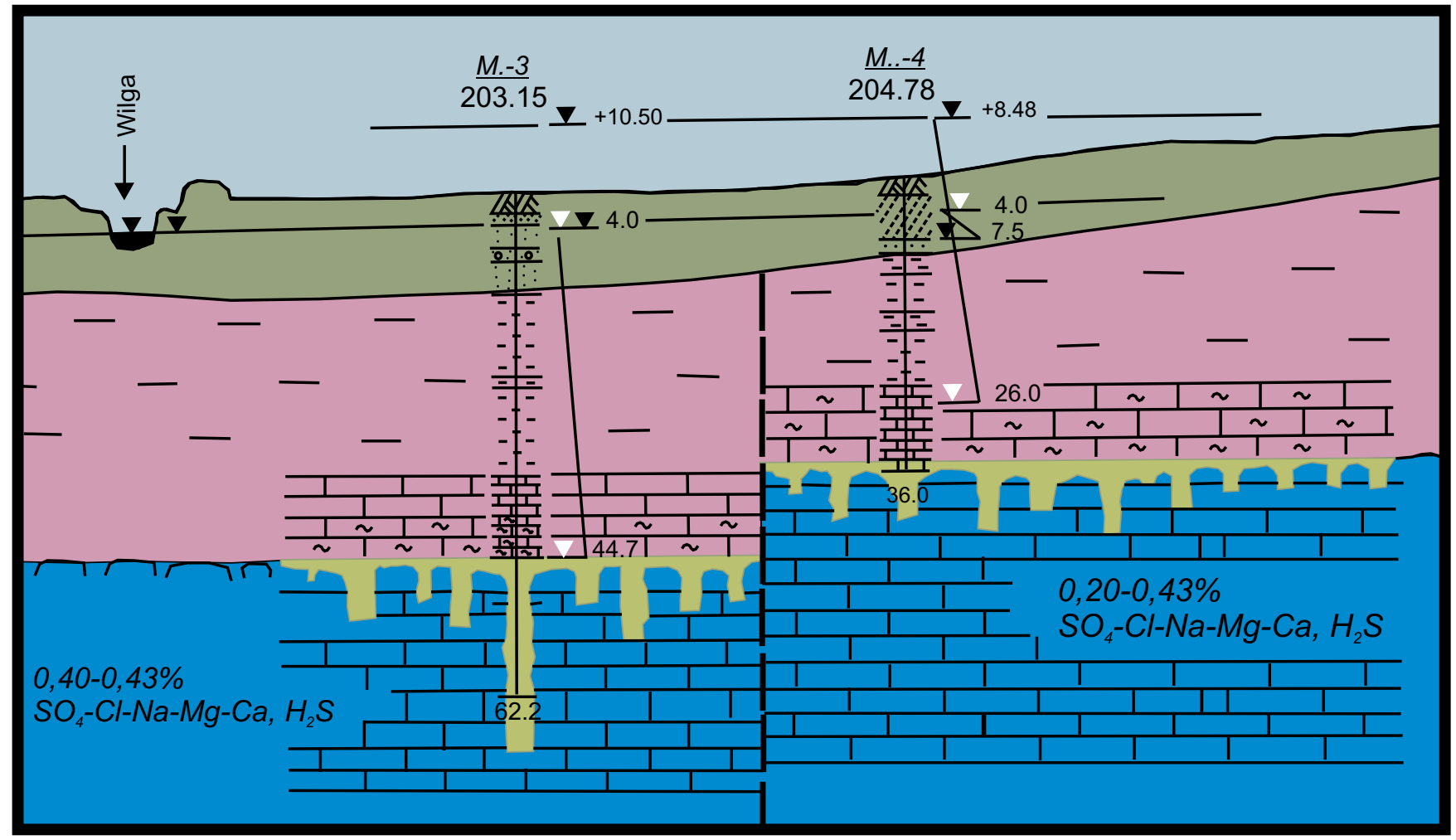

Fig. 18. Hydrogeological cross - section (after Radwan, Józefko, 1984) • Przekrój hydrogeologiczny (na podstawie Radwan, Józefko,1984)

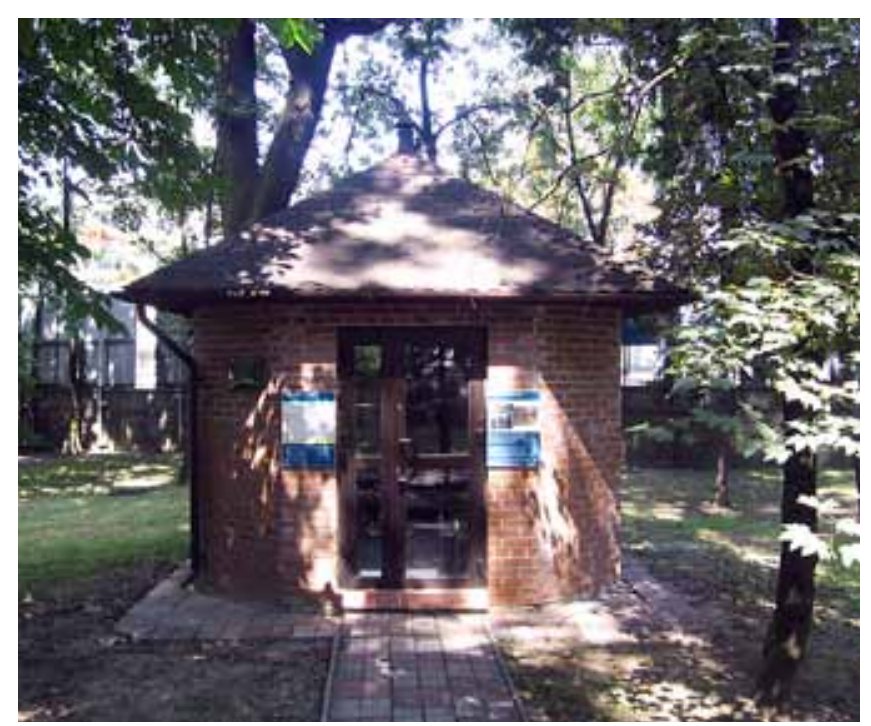

Fig. 19. Geo $-2 \mathrm{~A}$ boreholle, phot. I. Jamorska $\bullet$ Otwór Geo $-2 \mathrm{~A}$, fot. I. Jamorska

of the present owners to restore the glamour of this place, and taking into account the needs of a present-day consumer, to create a ,health resort" in the heart of Cracow. Relax Care Company has been operating there since 2005 offering its customers not only rehabilitation procedures but also various beauty treatments, massages, as well as cryo-sauna and a fitness centre (www.relaxcare.pl)

\section{Conclusions}

Spa tourism has every chance to develop in Poland. Polish health resorts employ very good medical staff who enable patients to use precious mineral waters properly. Besides, they are located in the places of special tourist interest. The area of Cracow is certainly a good example here as compared to other towns in Poland. It has plenty of sulphide mineral waters and also takes pride in its landscape, cultural and historical events. Rich traditions of the city are supplemented by contemporary artistic events of an international character. However the use of sulphide waters of Swoszowice, Krzeszowice and Mateczny in the development of spa tourism is restrained by the lack of appropriate infrastructure. These places are not properly promoted, and there are no funds to undertake modernisation works. Undoubtedly, funds coming from the European Union may become very helpful.

Weak and strong points as well as chances of the development of these places were presented with using SWOT analysis (Tab. 2). SWOT is often used as part of a strategic planning process. The SWOT framework was described in the late 1960's by Edmund P. Leared, C. Roland Christiansen, Kenneth Andrews and William D. Guth in Business Policy, Text and Cases. The SWOT analysis classifies the internal aspects of the company as strengths or weaknesses and the external situational factor as opportunities or threats. Strengths can serve as a foundation for building a competitive advantage, and weaknesses may hinder it (Alkhafaji, 2003).

Following the example of renowned European health resorts combining therapeutic and prophylactic functions with recreational tourism to meet the needs of younger people in the twenty-first century, Cracow has a good chance to develop spa tourism more effectively. It must be underlined that despite considerable progress in medicine and pharmacology sulphide waters still remain most effective in treating certain diseases. Therefore, it is crucial that these places should be promoted as not to be forgotten. 


\begin{tabular}{|c|c|}
\hline STRENGHTS & WEAKNESSES \\
\hline $\begin{array}{l}\text { - } \quad \text { Good location, close the city centre of Cracow. } \\
\text { - } \quad \text { Numironmental advantages. } \\
\text { - } \quad \text { Possibility of walks. } \\
\text { - } \quad \text { Diverse and rich mineral resources. } \\
\text { - } \quad \text { Eiverse healing profiles. } \\
\text { - } \quad \text { Availability of the gas mains, water supply } \\
\text { systems and energy network. }\end{array}$ & $\begin{array}{l}\text { - Weak marketing of the town. } \\
\text { - } \quad \text { Kroblems with communication (Swoszowice). } \\
\text { - } \quad \text { Insuvy traffic (Mateczny, Swoszowicent quality of tourism infrastructure. } \\
\text { - } \quad \text { Financial limited possibilities. } \\
\text { - } \quad \text { Enaotic development of Cracow. } \\
\text { - Insufficient use of historical, cultural and natural } \\
\text { features of the region with respect to tourism } \\
\text { development. }\end{array}$ \\
\hline OPPORTUNITIES & TREATS \\
\hline $\begin{array}{l}\text { - Promotion of the region. } \\
\text { - Investment in transport and environmental } \\
\text { infrastructure and their better management. } \\
\text { Better accessibility and quality of public } \\
\text { transport. } \\
\text { - New leisure trends. }\end{array}$ & $\begin{array}{l}\text { - Weakening of the competitive position of the region } \\
\text { due to dynamic development of spa tourism service } \\
\text { in other areas. } \\
\text { - Degradation of natural resources (therapeutic water). } \\
\text { - Conflict between development of tourism, transport, } \\
\text { industrial production and natural environment. } \\
\text { - Aggravation of the state of historical objects and } \\
\text { landscape. } \\
\text { Polluting the underground water and its } \\
\text { consequences for the ecosystems and health. }\end{array}$ \\
\hline
\end{tabular}

\section{Streszczenie}

\section{Znaczenie wód leczniczych Swoszowic, Krzeszowic i Matecznego dla rozwoju turystyki uzdrowiskowej}

\section{Izabela Jamorska}

Niniejsza praca dotyczy leczniczych wód Krakowa i okolic, a ściślej wód Krzeszowic, Swoszowic i Matecznego oraz możliwości ich wykorzystania dla rozwoju turystyki uzdrowiskowej. Występujące tu wody siarczkowe, mimo swych leczniczych właściwości nadal nie są w pełni wykorzystywane. Status uzdrowiska posiadają tylko Swoszowice. Biorąc pod uwagę lokalizacje ujęć tych wód, w pobliżu jednego z najlepiej rozwiniętych pod względem turystycznym miast Polski, powinny stać się one kolejną atrakcją dla turystów polskich i zagranicznych.

Badany obszar należy do województwa małopolskiego. Zgodnie z podziałem Polski na mezoregiony fizyczno - geograficzne według Kondrackiego (1998) obszar należy do kilku podprowincji: Wyżyny Śląsko - Krakowskiej, Wyżyny Małopolskiej, Północnego Podkarpacia, Zewnętrznych Karpat Zachodnich.

Z geologicznego punktu widzenia, region Krakowa znajduje się w szczególnym miejscu - na pograniczu wielkich jednostek strukturalnych. Należą do nich m.in. zapadlisko górnośląskie, monoklina śląsko - krakowska i niecka niedziańska, a także Karpaty, zapadlisko przedkarpackie i przedmurze Karpat. Powoduje to urozmaicenie i skomplikowanie tego obszaru, którego podstawowym elementem tektoniki są uskoki (Rutkowski, 1993).
Występowanie wód leczniczych jest ściśle związane z zapadliskiem przedkarpackim (Fig. 1.). Polskie zapadlisko przedkarpackie (długość $300 \mathrm{~km}$, szerokość do $100 \mathrm{~km}$ ) jest częścią wielkiego basenu sedymentacyjnego rozciągającego się wzdłuż łuku karpackiego. Na zachodzie zapadlisko przedkarpackie łączy się z alpejskim basenem molasowym, na wschodzie zaś z basenem przedgórskim Bałkanidów. Podobnie jak inne rowy przedgórskie zapadlisko to jest asymetryczne i wypełnione osadami mioceńskimi, których miąższość dochodzi do 3 kilometrów (Oszczypko i in., 2006).

Swoszowice, podobnie jak większość uzdrowisk polskich położone są w jednym $\mathrm{z}$ najpiękniejszych rejonów naszego kraju. Głównym bogactwem tego uzdrowiska są wody siarczkowe. Ich historia wiąże się nierozerwalnie z kopalnią siarki, która działała na tym obszarze od 1422 do 1786 r. Na terenie uzdrowiska występują wody siarczkowe typu: siarczanowowodorowęglanowo - wapniowo - magnezowe, którym swoistość nadaje siarkowodór (ok. $60 \mathrm{mg} / \mathrm{l}$ ) (Fig. 2). Jedynym eksploatowanym obecnie ujęciem wody leczniczej w obrębie obszaru górniczego Swoszowice jest „Źródło Główne” (Fig. 3.). Wodę tego samego typu posiada źródło Napoleon, które ujęte jest betonowym kręgiem. Wypływająca $\mathrm{z}$ niego woda nie jest wykorzystywana do celów leczniczych lecz wąską stróżką odprowadzana do rzeki Wilgi. Zbiornikiem wód leczniczych są utwory osiarkowanej serii gipsowej pocięte dawnymi wyrobiskami górniczymi. Ma on charakter szczelinowo-krasowy w związku z czym charakteryzuje się dużą przepuszczalnością i zdolnością gromadzenia wody. W spągu serii ewaporatów obecne są utwory klastyczne: zlepieńce, piaskowce i piaski oraz iłołupki silnie zapiaszczone. Podob- 
ne osady stwierdzone zostały w obrębie serii ewaporatowej (Kleczkowski, Myszka, 1989). Według Garlickiego spełniały one role kolektorów dla bituminów (głównie metanu) przeobrażających gips przy udziale mikroorganizmów.

Warunki najkorzystniejsze zarówno dla lecznictwa klimatycznego, jak i dla odpoczynku i relaksu panują w Parku Zdrojowym (Fig. 4). Istotne znaczenie ma występująca w powietrzu najwyższa zawartość roślinnych olejków eterycznych o właściwościach profilaktyczno - leczniczych w odniesieniu do choroby nadciśnieniowej, astmy, a także o cechach uspokajających (Porwisz A. i in., 2008). Obecnie Park Zdrojowy służy zarówno mieszkańcom, kuracjuszom jak i turystom. Przechodzą przez niego dwa szlaki turystyczne: niebieski i czarny. Ponadto występują tu dochodzące do 25 metrów wysokości drzewa liściaste, liczące nierzadko ponad 180 lat. Najcenniejsze $\mathrm{z}$ nich zostały zaliczone do pomników przyrody.

Zakład Przyrodoleczniczy mieści się w łazienkach w starym budynku. Zabiegi w zakresie elektroterapii wykonywane są w zmodernizowanym pawilonie „Parkowa” (Fig. 5). W istniejącym kompleksie budynków, wykonywane są następujące zabiegi: kąpiele siarczane, borowina, masaż podwodny, wirowy oraz suchy, naświetlanie: diadynamik, terapuls, jonoforeza, akupresura. W dotychczasowej działalności Zakładu wodoleczniczego, stwierdzono szczególnie wysoką skuteczność leczenia chorych z reumatoidalnym zapaleniem stawów oraz z zesztywniającym zapaleniem stawów kręgosłupa.

Obecnie uzdrowiska pełnią dwie podstawowe funkcje: leczniczą oraz turystyczną. Z przytoczonych powyżej faktów wynika, że Swoszowice spełniają wszystkie wymagania zawarte w Polskiej Normie PN-91/ZZ-11000 dotyczące uzdrowisk. Pozostaje kwestia drugiej funkcji jaką jest turystyka. Wiele polskich jak i zagranicznych uzdrowisk wykorzystuje swoje położenie geograficzne do rozwijania w nich poza zabiegami leczniczymi również aktywnych form wypoczynku. Również Swoszowice mogą zaoferować kuracjuszom odmienną od leczniczego formę wypoczynku. Wojewódzki klub sportowy Krakus posiada w Swoszowicach trzy sekcje sportowe: piłki nożnej, kolarską oraz jeździecką. Ośrodek jeździecki prowadzi działalność nauki jazdy konnej, zawodniczą oraz rehabilitacji. Szczególnie ta ostatnia dotycząca rehabilitacji dzieci z porażeniem mózgowym przy zastosowaniu oddziaływania bioprądami powstałymi podczas jazdy na grzbietach koni, w połączeniu z zabiegami w Zakładzie Przyrodoleczniczym, zyskała duże uznanie w kraju. Najbardziej zalecanym sposobem rekonwalescencji dla starszych kuracjuszy są spacery po Parku Zdrojowym, wyznaczonymi alejkami spacerowymi i ścieżkami turystycznymi. Pobyt w uzdrowisku można wzbogacić o wycieczkę do słynnego Sanktuarium Bożego Miłosierdzia w Krakowie Łagiewnikach (turystyka pielgrzymkowa) oraz zwiedzanie historycznych miejsc miasta Kraków jakim jest niewatpliwie m.in. Wawel. Swoszowice oddalone są od centrum Krakowa o ok. 3 km. Podobna odległość dzieli je od słynnej kopalni soli w Wieliczce. Poza zwiedzaniem kopalni, również tam kuracjusze mogą oddać się dobroczynnemu działaniu soli w specjalnie do tego celu przystosowanych grotach.
Krzeszowice leżą w obrębie Wyżyny Krakowskiej, w centrum Rowu Krzeszowickiego, 25 km na zachód od Krakowa (Fig. 6). W tej okolicy Rów Krzeszowicki zwęża się do szerokości ok. $2 \mathrm{~km}$ i jest najbardziej malowniczy pod względem krajobrazowym oraz urozmaicony geomorfologicznie i geologicznie. Na terenie Krzeszowic udokumentowano dwa poziomy wód mineralnych, o zróżnicowanym chemizmie i różnych głębokościach występowania. Niższy poziom występuje w spękanych i skrasowiałych wapieniach górnej jury, które charakteryzują dogodne warunki przewodzenia i magazynowania wód, podobnie jak leżące powyżej osady piaszczyste kredy i paleogenu. Drugi, wyższy poziom związany jest z gipsami miocenu, w których obserwuje się ślady rozmyć krasowych oraz liczne spękania i szczeliny. Dzięki ich obecności oraz procesom krasowym, zespół osadów z gipsami jest miejscem akumulacji i krążenia wód mineralnych typu siarczanowego (Ney, 2002). Wody mineralne Krzeszowic ujmowane są obecnie przez źródło „Zdrój Główny” (Fig. 7), którego zasoby eksploatacyjne wynoszą $1,61 \mathrm{~m}^{3} / \mathrm{h}$ przy depresji równej $2,3 \mathrm{~m}$. Jest to źródło naturalne, ujęte studnią o głębokości 4,76 m. Wypływa z niego woda typu $\mathrm{SO}_{4}-\mathrm{HCO}_{3}-\mathrm{Ca}-\mathrm{Mg}, \mathrm{H}_{2} \mathrm{~S}$ i zawartości $\mathrm{H}_{2} \mathrm{~S}$ ok. $6 \mathrm{mg} / \mathrm{l}$ (Fig. 8). Pierwotnie zbiornikiem wody siarczkowej była Kapliczka. Pompowano za jej pomocą wodę ze Zdroju Głównego, a następnie drewnianymi rurami doprowadzano do łazienek (Fig. 9). Z początkiem 1999 roku ośrodek zaczął działać jako Samodzielny Zakład Opieki Zdrowotnej Ośrodek Rehabilitacji Narządu Ruchu Krzeszowice (Fig. 10). Podobnie jak Swoszowice poza obecnością cennych wód leczniczych Krzeszowice i okolice moga poszczycić się wieloma zabytkami (Fig. 11, 12, 13), licznymi szlakami pieszymi i rowerowymi. Za rozwojem turystyki na tym obszarze przemawia również obecność licznych Parków Krajobrazowych (Fig. 15) i Rezerwatów przyrody. Przebiega tędy także Podkrakowski Szlak Papieski upamiętniający wycieczki piesze i rowerowe ks. Karola Wojtyły oraz Szlak Maryjny (Fig. 16). Kuracjusze mogą odbywać wycieczki dydaktyczne między innymi szlakiem górnictwa węglowego, architektury drewnianej, a także ścieżką edukacyjną, prowadząca przez teren dawnej klauzury papieskiej i prezentującą walory przyrodnicze Rezerwatu Dolina Eliaszówki oraz walory kulturowe zespołu klasztornego Karmelitów Bosych w Czernej (www.krzeszowice.pl).

Za rozwojem turystyki uzdrowiskowej na tym terenie przemawia również dobrze rozwinięta sieć komunikacyjna. Obecność lotniska, a także coraz większa ilość tanich linii lotniczych sprawia, że jest to miejsce dostępne również dla obcokrajowców. Zarówno Swoszowice jak i Krzeszowice aby zaistnieć na rynku turystycznym powinny dostosować się do panujących obecnie trendów. Bezdyskusyjnie miejsca te posiadaja przewage nad innymi terenami rekreacyjnymi występowaniem wody leczniczej a co za tym idzie wielowiekowej tradycji wyjazdu do wód. Bogata historia tych miejsc, bezpośrednie obcowanie z przyrodą są bez wątpienia wielkimi atutami w dobie społeczeństwa żyjącego w ciągłym pośpiechu głównie w dużych miastach. Lecznictwo uzdrowiskowe w ostatnich latach uległo znacznej przemianie w wielu krajach europejskich. Uzdrowiska nie są postrzegane obecnie jako miejsca dla ludzi w podeszłym wieku. Coraz więcej młodych ludzi zaczęło doceniać uroki uzdrowisk 
szukając w nich możliwości nie tylko regeneracji sił ale również atrakcji w formie aktywnego wypoczynku. Coraz więcej uzdrowisk europejskich dostrzegając potrzeby młodego społeczeństwa dostosowała się do nich tworząc jakże popularne ośrodki SPA lub Wellness.

Miejscem, które w znacznym stopniu dostosowało się do obecnie panującej mody na usługi uzdrowiskowo turystyczne jest Kraków Mateczny (Fig. 16). Ewenementem w skali całego kraju jest fakt że występujące tu siarczkowe wody lecznicze zlokalizowane są przy skrzyżowaniu ronda Mateczny w centrum Krakowa. Wody siarczkowe zostały odkryte przypadkowo podczas prac poszukiwawczych wody słodkiej w ogrodzie Antoniego Matecznego. Na bazie tej wody w 1905 r. uruchomiony został Zakład Kąpielowy Siarczanowo - solankowy nazywany potocznie Matecznym (Fig. 17). Warunki hydrogeologiczne występowania wód są dość dobrze rozpoznane dzięki licznym otworom. Są one związane z głębokimi kieszeniami krasowymi w wapieniach jurajskich wypełnionymi drobnoziarnistymi piaskami wieku paleogeńskiego i z wapieniami marglistymi trzeciorzędu (Fig. 18). We wszystkich otworach Matecznego stwierdzono dwa poziomy wodonośne: górny swobodny z wodą słodką, związany jest z utworami czwartorzędowymi, oraz dolny artezyjski z wodą mineralną, związany z utworami trzeciorzędowymi (Kleczkowski, Myszka, 1989).

Złoże wód mineralnych oddzielają od czwartorzędowego poziomu wodonośnego w piaskach żwirach, wapienie margliste i iły mioceńskie. To właśnie te osady w naturalny sposób chronią złoże przed zanieczyszczeniami antropogenicznymi, na które narażone są wody ze względy na położenie w centrum aglomeracji miejskiej. Obecnie na Matecznym znajdują się trzy ujęcia wód: otwór M-3, M-4 i Geo-2A (Fig. 19). Występujące tu wody siarczkowe wykorzystywane są głównie do kąpieli leczniczych. Umożliwiają one leczenie dolegliwości reumatycznych, pourazowe narządu ruchu oraz choroby skóry. Od 1970 roku wody te ze względu na wysoką zawartość cennych dla organizmu biopierwiastków rozlewano pod handlowa nazwą „Krakowianka”. Ogromną zaletą tej wody jest wzajemna proporcja pomiędzy zawartością wapnia i magnezu w jednym litrze, która gwarantuje najlepszą przyswajalność przez organizm (Rajchel L., 2000).

\section{References (Literatura)}

Alkhafaji A., 2003. Strategic Management. Haworth Press.

Burzyński T., Dryglas D., Golba J., Bartosik A., 2005: Czynniki wptywajace na jakość i konkurencyjność usług turystycznych w miejscowościach uzdrowiskowych. Instytut Turystyki w Krakowie, Sp. Z o. o.

Dukiet M., 1967. Wody mineralne i kapiele lecznicze. Wyd. PAN - Oddział w Krakowie. Tom 43.

Golba J., 2007. Perspektywa rozwoju polskich uzdrowisk. Jedziemy do Wód w... .-2007, 2, 29-33.

Gradziński R., 1972. Przewodnik geologiczny po okolicach Krakowa. Wyd Geol., Warszawa.

Gradziński R., 1993. Mapa geologiczna obszaru krakowskiego bez osadów czwartorzędowych i lądowych utworów trzeciorzędowych.

Jagusiewicz A., 2002. Infrastruktura turystyki uzdrowiskowej $w$ Polsce. Warszawa, s. 55.

Jeleń B., 2005. Turystyka w miejscowościach uzdrowiskowych. Stowarzyszenie ekonomistów rolnictwa i agrobiznesu. Roczniki Naukowe SERiA VII.

Kleczkowski A. S., Myszka J. 1989. Hydrogeologia Krakowa [W:] Przew. LX Zjazdu PTG, 14-16 września, Kraków. s. 170-174.

Ney R., 2002. Modelowe studium kompleksowego wykorzystania i ochrony surowców balneologicznych Krakowa i okolic. Wyd. Inst. GSMiE PAN, Kraków.
Oszczypko N., Krzywiec P., Papadyuk I., Peryt T., 2006. Carpathian Foredeep Basin (Poland and Ukraine): Its Sedimentary, Structural, and Geodynamic Ewolution. In: J. Golonka and F. J. Picha, eds.,The Carpathians and their foreland: Geology and hydrocarbon resources: $A A P G$, Memoir 84: 293-350.

Porwisz A., Porwisz B., Grządziel A., Janusz M., 2008. Operat Uzdrowiska Swoszowice gminy miejskiej Kraków.

Radwan J., Józefo I., 1984. Dokumentacja hydrogeologiczna zasobów wód podziemnych dla celów leczniczych z utworów trzeciorzędowych w kat. „B” dla zaopatrzenia Zakładu ,Mateczny” w Krakowie. Przedsiębiorstwo hydrogeologiczne, Kraków.

Rajchel L., 2000. Uzdrowisko nie uzdrowione. Geoturystyka dla każdego. Dziennik Polski, 25.

Rutkowski J., 1993. Objaśnienia do Szczegółowej Mapy Geologicznej Polski w skali1:50000, Arkusz Kraków (973). Państwowy Instytut Geologiczny, Warszawa: 5-46.

Ryba B., 2005. Szczęśliwy kogo widok tych wdzięków zachwyca, z których stynie Krzeszowic pyszna okolica. Multis Multum, 2005, s. 12-13.

Uchwała Nr XXVIII/249/2004 Rady Miejskiej w Krzeszowicach z dnia 23. 12. 2004 r. Dziennik Urzędowy Województwa Małopolskiego, nr 209.

Websites (Strony internetowe):

http://malopolskie.parki.org/krkswoszowice2/

http://www.relaxcare.pl/

http://www.krzeszowice.net4.pl/

http://www.bip.krakow.pl 